\title{
PENGARUH PROBLEM BASED LEARNING TERHADAP KEMAMPUAN PENALARAN MATEMATIS DAN KEMAMPUAN PEMECAHAN MASALAH
}

\section{(THE EFFECT OF PROBLEM BASED LEARNING ON REASONING ABILITY AND PROBLEM SOLVING)}

\author{
Sri Kusuma Dewi Alfiah ${ }^{1}$, Suharti Kadar ${ }^{2}$, Ahmad Hatip ${ }^{3}$ \\ ${ }^{1}$ Universitas Dr.Soetomo, srikusumadewi3@gmail.com. \\ ${ }^{2}$ Universitas Dr.Soetomo, suhartikadar@yahoo.co.id. \\ ${ }^{3}$ Universitas Dr.Soetomo, ahmad.hatip@unitomo.ac.id.
}

\begin{abstract}
Abstrak
Tujuan dari penelitian ini adalah 1) Untuk mengetahui pengaruh pembelajaran Problem Based Learning terhadap kemampuan penalaran matematis siswa pada materi SPLTV yang diterapkan kepada siswa. 2) Untuk mengetahui pengaruh pembelajaran Problem Based Learning terhadap kemampuan pemecahan masalah siswa pada materi SPLTV yang diterapkan kepada siswa. Penelitian ini menggunakan pendekatan kuantitatif dan jenis penelitian adalah quasi eksperimen. Populasi dalam penelitian ini aadalah kelas X SMAN 22 Surabaya, sedangkan sampel yang digunakan adalah kelas X IPA-1 dan X IPA-4 SMAN 22 Surabaya. Instrumen pada penelitian ini adalah berupa tes. Teknik analisis data menggunakan analisis independent sampel $\mathrm{t}$ tes. Hasil pada penelitian ini menunjukkan ada perbedaan kemampuan penalaran matematis dan pemecahan masalah siswa yang diberikan pembelajaran Problem Based Learning dengan siswa yang diberikan pembelajaran konvensional
\end{abstract}

Kata kunci: problem based learning, penalaran, pemecahan masalah.

\begin{abstract}
The purpose of this study is 1) To determine the effect of Problem Based Learning learning on students' mathematical reasoning abilities in the SPLTV material applied to students. 2) To determine the effect of Problem Based Learning on students' problem solving abilities in the SPLTV material applied to students. This research uses a quantitative approach and the type of research is quasi-experimental. The population in this study was class $X$ SMAN 22 Surabaya, while the sample used was class X IPA-1 and X IPA-4 SMAN 22 Surabaya. The instrument in this study is a test. The data analysis technique used independent samples $t$ test analysis. The results of this study indicate that there are differences in the mathematical reasoning and problem solving abilities of students who are given Problem Based Learning with students who are given conventional learning
\end{abstract}

Keywords: problem based learning, reasoning, problem solving

\section{PENDAHULUAN}

Indonesia termasuk dalam negara berkembang karena memiliki sumber daya manusia dengan mutu dan prestasi di bawah negara lain yaitu Singapura, Vietnam, dan Malaysia. Dengan adanya fakta ini, maka perlu adanya peningkatan mutu manusia. Dalam dunia pendidikan sendirimasing-masing individu dituntut 
untuk memiliki karakter yang baik dan berkualitas, sehingga mampu untuk memahami potensinya, dan mengenal Tuhannya. Dari permasalahan tersebut pemerintah berupaya mengatasi dengan berbagai strategi, salah satunya adalah penerapan kurikulum yang sesuai dengan sistem pendidikan di Indonesia. Selain itu pada penerapannya yang harus pandai mengolah kelas adalah guru sebagai pendidik, karena perkembangan pola pikir siswa juga dipengaruhi oleh kesesuaian dalam menerapkan metode pembelajaran. Dalam pembelajaran matematika kemampuan siswa tidak hanya pada berhitung saja, akan tetapi kemampuan bernalar secara logis dan kritis untuk memecahkan masalah (Kusumawardani, Wardono, and Kartono 2018). Penalaran sendiri memiliki peran yang penting dalam matematika, karena dapat dijadikan sebagai kemampuan dasar bagi standar tahapan lainnya. Selain itu, keterkaitan antara matematika dan penalaran tidak dapat dipisahkan dalam menyelesaikan permasalahan matematika membutuhkan penalaran.

Di samping itu, kemampuan pemecahan masalah adalah salah satu unsur yang penting untuk meningkatkan kemampuan berpikir pada siswa. Kemampuan pemecahan masalah yang baik pada matematika dapat memahami persoalan matematika, memahami konsep, menyusun permasalahan dalam model matematika, serta dapat menyelesaikan masalah dan menyimpulkan penyelesaian yang didapat (Purnamasari 2015). Dalam penerapannya pembelajaran matematika, guru masih menggunakan metode konvensional. Metode pembelajaran ini masih dianggap sebagai metode pembelajaran yang efektif. Pembelajaran matematika memiliki tujuan pada kurikulum khusus pelajaran matematika adalah menekankan siswa pada proses pemecahan masalah yang dapat ditemui pada masalah nyata. Artinya dalam pembelajaran matematika siswa harus mempunyai kemampuan dasar yaitu memecahkan masalah. Karena pembelajaran matematika cenderung menggunakan konsep pembelajaran yang melatih proses pemecahan masalah. Sehingga mengharuskan siswa agar memahami masalah, dapat membuat permodelannya, dan mendapatkan penyelesaian yang sesuai dengan permasalahan yang muncul. Menyadari pentingnya kemampuan penalaran dan pemecahan masalah pada matematika maka perlu adanya upaya perbaikan untuk meningkatkan pembelajaran matematika, yaitu membuat inovasi dalam pembelajaran dengan menerapkan model pembelajaran yang sesuai, salah satunya adalah dengan menerapkan Problem based learning. Memasuki abad 21 ini yang dikenal dengan abad pengetahuan, karena landasan aspek dalam kehidupan bermula dari pengetahuan. Selain itu, banyak perubahan yang terjadi di era sekarang ini dikarenakan terjadinya perkembangan teknologi yang sangat pesat, terutama pada pembelajaran sekarang ini yang menuntut siswa untuk terlibat aktif dan kreatif. Oleh karena itu, bentuk pembelajaran seperti Problem based learning dianggap sesuai dengan sistem pembelajaran sekarang agar inovatif.

Problem based learning merupakan pembelajaran yang diawali dengan masalah kontekstual dan memiliki karakteristik antara lain, membangun pembentukan pemahaman masalah yang disajikan, pembelajaran berpusat pada siswa, menimbulkan interaksi dari kegiatan diskusi dan tanya jawab (Wulandari 2018). Berdasarkan informasi dari guru terdapat permasalahan dalam pembelajaran matematika, yaitu siswa kelas $X$ masih kesulitan dalam proses penalarannya dan pemecahan masalah yang harus diambil. Sehingga proses pembelajaran terkesan tidak menarik dan membosankan, terlebih lagi materi 
matematika dianggap sulit dan kurang menarik. Berdasarkan hasil observasi tersebut, penyebab keadaan siswa kurang dalam memecahkan masalah dan penalaran masih rendah yaitu: 1) Model pembelajaran yang diterapkan kurang mendukung untuk merangsang proses penalaran dan kemampuan pemecahan masalah siswa. 2) Pembelajaran belum diawali dengan apersepsi dari guru pengajar sehingga pola pikir siswa belum terbuka secara luas. 3) Guru masih kurang mengarahkan siswa untuk memecahkan masalah yang dapat mendorong proses penalaran siswa. 4) Guru masih seringkali menjadi pusat pembelajaran dikelas, sehingga pembelajaran tidak berkembang dan tidak memberikan peluang kepada siswa untuk mengkomunikasikan pemikirannya.

Beberapa penelitian yang relevan dengan penelitian ini adalah sebagai berikut : penelitian yang berjudul "Pembelajaran Problem Based Learning Untuk Meningkatkan Kemampuan Pemecahan Masalah Matematis Dan Self Efficacy Mahasiswa Calon Guru" menghasilkan kemampuan pemecahan masalah mahasiswa dengan menerapkan metode problem based learning lebih baik daripada kemampuan pemecahan masalah mahasiswa yang diberikan metode ekspositori (Sariningsih and Purwasih 2017). Selain itu pembelajaran problem based learning berpengaruh pada self efficacy mahasiswa.

Penelitian yang dilakukan oleh Frisca Wulandari dengan judul "Keterkaitan Kemampuan Penalaran Matematis Siswa Dengan Model Problem Based Learning (PBL)" menyimpulkan bahwa proses pembelajaran dengan menerapkan model Problem Based Learning memiliki keterkaitan dengan kemampuan penalaran matematis (Wulandari 2018). Karena pada kegiatan inti PBL berpeluang besar untuk siswa dapat menggunakan penalaran pada pola dan sifat, melakukan manipulasi matematika dalam membuat generalisasi, menyusun bukti atau menjelaskan gagasan. Problem based learning memiliki karakteristik diantarnya yaitu : 1) Memfokuskan siswa menjadi subyek utama. Sehingga PBL memiliki hubungan dengan teori konstruktivisme agar siswa dapat mengambangkan pengetahuan yang diketahuinya. 2) Memberikan masalah nyata agar mereka dapat mengerti persoalan tersebut dan menerapakannya dalam kehidupan sehari-hari. 3) Memperoleh informasi baru melalui pembelajaran mandiri. 4) Pembelajaran bisa dilaksanakan dengan membentuk kelompok kecil agar terjadi interaksi. 5) Guru bertindak sebagai fasilitator (Liu 2005).

Berdasarkan uraian latar belakang dan masalah di atas tujuan dari penelitian ini adalah 1) untuk mengetahui perbedaan kemampuan penalaran matematis siswa yang diberikan pembelajaran Problem Based Learning dengan siswa yang diberikan pembelajaran konvensional pada materi SPLTV. 2) Untuk mengetahui perbedaan kemampuan pemecahan masalah matematis siswa yang diberikan pembelajaran Problem Based Learning dengan siswa yang diberikan pembelajaran konvensional pada materi SPLTV.

\section{METODE PENELITIAN}

Penelitian ini menggunakan pendekatan kuatitatif dengan jenis penelitian quasi eksperimen. Subyek pada penelitian ini adalah siswa kelas X SMAN 22 Surabaya. Rancangan penelitian yang digunakan dalam penelitian ini diambil dari pretest-postest control group design karena ada dua kelas yang dibandingkan dengan memberikan perlakuan yang berbeda. Dengan menggunakan desain ini kelas eksperimen dan kelas kontrol memiliki karakterisrik yang sama karena 
diambil secara acak dari populasi yang homogen. Pada desain ini tahap awal yang dilakukan adalah kedua kelomok diberi pretest dengan tes yang sama. Kelas eksperimen akan diberikan pembelajaran problem based learning sedangkan kelas kontrol diberi pembelajaran konvensional, dan kelas uji coba instrument. Setelah diberikan perlakuan pada masing-masing kelas maka langkah selanjutnya adalah memberikan postest. Desain penelitian disajikan dalam tabel sebagai berikut :

Tabel 1. Desain Penelitian

\begin{tabular}{c|c|cc}
\hline$R$ & O1 & X1 & O2 \\
\hline R & O3 & X2 & O4 \\
\hline
\end{tabular}

Keterangan :

$\mathrm{R}=$ Kelas hasil pengacakan (random)

$\mathrm{O} 1=$ Pretest kelas eksperimen.

$\mathrm{O} 2=$ Postest kelas eksperimen.

$\mathrm{X} 1=$ Perlakuan dengan Problem Based Learning

O3 = Pretest kelas kontrol.

$\mathrm{O} 4=$ Postest kelas kontrol.

X2 = Pembelajaran konvesional

Penelitian ini dilaksanakan di kelas X IPA SMAN 22 Surabaya, dan sampel yang diambil terdiri dari 2 kelas dari keseluruhan kelas X IPA. Satu kelas sebagai kelas eksperimen yaitu kelas X IPA-1 sebanyak 35 siswa, dan kelas X IPA-4 sebanyak 35 siswa sebagai kelas kontrol. Metode pengumpulan data menggunakan tes kemampuan penalaran dan pemecahn masalah yang berupa soal essay. Setiap soal diberi skor sesuai dengan indicator penalaran dan pemecahan masalah. Metode analisis data menggunakan Independent sample test. Adapun variabel dalam penelitian ini adalah variabel bebas yaitu model pembelajaran problem based learning (X), sedangkan variabel terikat yaitu kemampuan penalaran (Y1) dan pemacahan masalah (Y2). Data yang diperoleh dari hasil tes yang sesuai dengan masing-masing indikator diolah melalui beberapa proses berikut :

1. Memberikan skor jawaban pretes dan postes sesuai dengan kunci jawaban dan pedoman penskoran masing-masing indikator.

2. Membuat tabel hasil pretes dan postes kelas eksperimen dan kelas kontrol.

3. Melakukan uji normlitas data dan uji homogenits data pretes dan postest yang diperoleh.

4. Menguji perbedaan rata-rata, dalam hal ini antara kelas eksperimen dan kelas kontrol, dengan menggunakan uji statistik yaitu uj-t.

Semua pengolahan data menggunakan bantuan software SPSS 25 dan Microsoft excel 2007. Pada tahap uji normalitas dan homogenitas atau pengujian prasyarat menunjukan hasil data berdistribusi normal dengan menggunakan uji komogorov smirnov dan dengan menggunakan uji levene statistic diketahui data memiliki varian yang homogen sehingga dapat dilakukan pengujian hipotesis penelitian.Uji hipotesis dalam penelitian ini untuk mencari perbedaan kemampuan penalaran matematis siswa yang diajar menggunakan model pembelajaran problem based learning dengan yang diajar menggunakan model pembelajaran 
konvensional dan perbedaan kemampuan pemecahan masalah siswa yang diajar menggunakan model pembelajaran problem based learning dengan yang diajar menggunakan model pembelajaran konvensional.

\section{HASIL DAN PEMBAHASAN}

Penelitian ini melibatkan dua kelas sebagai sampel, diantaranya satu kelas sebagai kelas eksperimen dan yang lain sebagai kelas kontrol. Sebelum pemberian perlakuan untuk mengukur kemampuan awal siswa diperoleh dari nilai pretest kemampuam penalaran dan pemecahan masalah di kelas eksperimen dan kelas kontrol. Untuk mengetahui seberapa besar kemampuan penalaran pada kedua kelas maka dilakukan pengujian hipotesis data pretes dan postes sebagai berikut :

1. Uji Normalitas

Tabel 2. Uji Normalitas Penalaran

\begin{tabular}{l|l|c}
\hline \multicolumn{1}{c|}{ Hasil } & \multicolumn{1}{|c|}{ Kelas } & Sig \\
\hline \multirow{2}{*}{ Pretes } & Eksperimen & 0,200 \\
\cline { 2 - 3 } & Kontrol & 0,068 \\
\hline \multirow{2}{*}{ Postest } & Eksperimen & 0,155 \\
\cline { 2 - 3 } & Kontrol & 0,088 \\
\hline
\end{tabular}

Dari hasil perhitungan SPSS 25.0 diperoleh nilai probabilitas (Asymp.sig) hasil pretes dan postes kemampuan penalaran pada kedua kelompok > 0,05 sehingga $\mathrm{H} 0$ diterima yang artinya data berdistribusi normal.

Tabel 3.Hasil Pretes dan Postes

\begin{tabular}{l|l|c}
\hline \multicolumn{1}{c|}{ Hasil } & \multicolumn{1}{|c|}{ Kelas } & Sig \\
\hline \multirow{2}{*}{ Pretes } & Eksperimen & 0,200 \\
\cline { 2 - 3 } & Kontrol & 0,064 \\
\hline \multirow{2}{*}{ Postest } & Eksperimen & 0,190 \\
\cline { 2 - 3 } & Kontrol & 0,182 \\
\hline
\end{tabular}

Dari hasil perhitungan SPSS 25.0 diperoleh nilai probabilitas (Asymp.sig) hasil pretes dan postes kemampuan pemecahan masalah pada kedua kelompok > 0,05 sehingga $\mathrm{Ho}$ diterima yang artinya data berdistribusi normal.

2. Uji Homogenitas

Tabel 4. Uji Homogenitas

\begin{tabular}{c|l|c}
\hline \multicolumn{1}{c|}{ Hasil } & \multicolumn{1}{|c|}{ Kelas } & Sig \\
\hline \multirow{2}{*}{ Penalaran } & Pretes & 0,230 \\
\cline { 2 - 3 } & Postes & 0,061 \\
\hline \multirow{2}{*}{ Pemecahanmasalah } & Pretes & 0,203 \\
\cline { 2 - 3 } & Postes & 0,302 \\
\hline
\end{tabular}

Dari hasil perhitungan SPSS 25.0 diperoleh nilai probabilitas (Asymp.sig) hasil pretes dan postes penalaran matematis > 0,05 sehingga $\mathrm{H} 0$ diterima yang artinya data berdistribusi normal. Sedangkan nilai probabilitas (Asymp.sig) hasil pretes dan postes kemampuan pemecahan masalah > 0,05 sehingga $\mathrm{H}_{0}$ diterima yang artinya data berdistribusi normal.

\section{Uji Hipotesis}


Setelah uji prasyarat telah dipenuhi maka uji t dapat dilakukan untuk mengetahui apakah tidak ada perbedaan rata-rata hasil kemampuan awal siswa antara kelas eksperimen dengan kelas kontrol dengan bantuan software SPSS 25 adalah sebagai berikut :

Tabel 5. Uji Hipotesis

\begin{tabular}{|c|c|c|c|c|c|}
\hline \multicolumn{6}{|c|}{ Group Statistics } \\
\hline & KELAS & $\mathrm{N}$ & Mean & Std. Deviation & $\begin{array}{l}\text { Std. Error } \\
\text { Mean }\end{array}$ \\
\hline \multirow[t]{2}{*}{ HASIL } & IPA 1 & 35 & 67.57 & 14.722 & 2.488 \\
\hline & IPA 4 & 35 & 65.43 & 11.843 & 2.002 \\
\hline
\end{tabular}

Berdasarkan hasil perhitungan SPSS di atas dapat diketahui bahwa jumlah siswa kelas X IPA-1 (eksperimen) adalah 35 orang dengan nilai rata-rata 67,57. Sedangkan jumlah siswa kelas X IPA 4 (kontrol) adalah 35 orang dengan nilai rata-rata 65,43 .

Tabel 6. Hasil Uji-t untuk Nilai Pretest

\begin{tabular}{|c|c|c|c|c|c|c|c|c|}
\hline \multicolumn{9}{|c|}{ Independent Samples Test } \\
\hline & & \multicolumn{2}{|c|}{$\begin{array}{l}\text { Levene's Test } \\
\text { forEquality } \\
\text { of Variances }\end{array}$} & \multicolumn{5}{|c|}{ t-test for Equality of Means } \\
\hline & & $\mathrm{F}$ & Sig. & $\mathrm{t}$ & Df & $\begin{array}{l}\text { Sig. } \\
(2- \\
\text { taile } \\
\text { d) }\end{array}$ & $\begin{array}{l}\quad \text { Mean } \\
\text { Differen } \\
\text { ce }\end{array}$ & $\begin{array}{l}\text { Std. } \\
\text { Error } \\
\text { Differen } \\
\text { ce }\end{array}$ \\
\hline \multirow[t]{2}{*}{ HASIL } & $\begin{array}{l}\text { Equal } \\
\text { variances } \\
\text { assumed }\end{array}$ & 1.467 & .230 & .671 & 68 & .505 & 2.143 & 3.194 \\
\hline & $\begin{array}{l}\text { Equal } \\
\text { variancesnot } \\
\text { assumed }\end{array}$ & & & .671 & 65.016 & .505 & 2.143 & 3.194 \\
\hline
\end{tabular}

Berdasarkan tabel hasil perhitungan SPSS di atas diperoleh nilai probabilitas (Asymp.Sig(2-tailed) adalah 0,505 > 0,05, sehingga H0 diterima yang artinya tidak ada perbedaan kemampuan penalaran matematis siswa antara kelas X IPA 1 (eksperimen) dan kelas X IPA 4 (kontrol).

Tabel 7. Nilai Postest

\begin{tabular}{|c|c|c|c|c|c|}
\hline \multicolumn{6}{|c|}{ Group Statistics } \\
\hline & KELAS & $\mathrm{N}$ & Mean & Std. Deviation & $\begin{array}{l}\text { Std. Error } \\
\text { Mean }\end{array}$ \\
\hline HASIL & IPA 1 & 35 & 81.86 & 10.296 & 1.740 \\
\hline & IPA 4 & 35 & 74.71 & 13.336 & 2.254 \\
\hline
\end{tabular}

Berdasarkan hasil perhitungan SPSS di atas dapat diketahui bahwa jumlah siswa kelas X IPA-1 (eksperimen) adalah 35 orang dengan nilai rata-rata 81.86. Sedangkan jumlah siswa kelas X IPA-4 (kontrol) adalah 35 orang dengan nilai rata-rata 74.71.

Tabel 8. Uji t Postes Penalaran 


\section{Independent Samples Test}

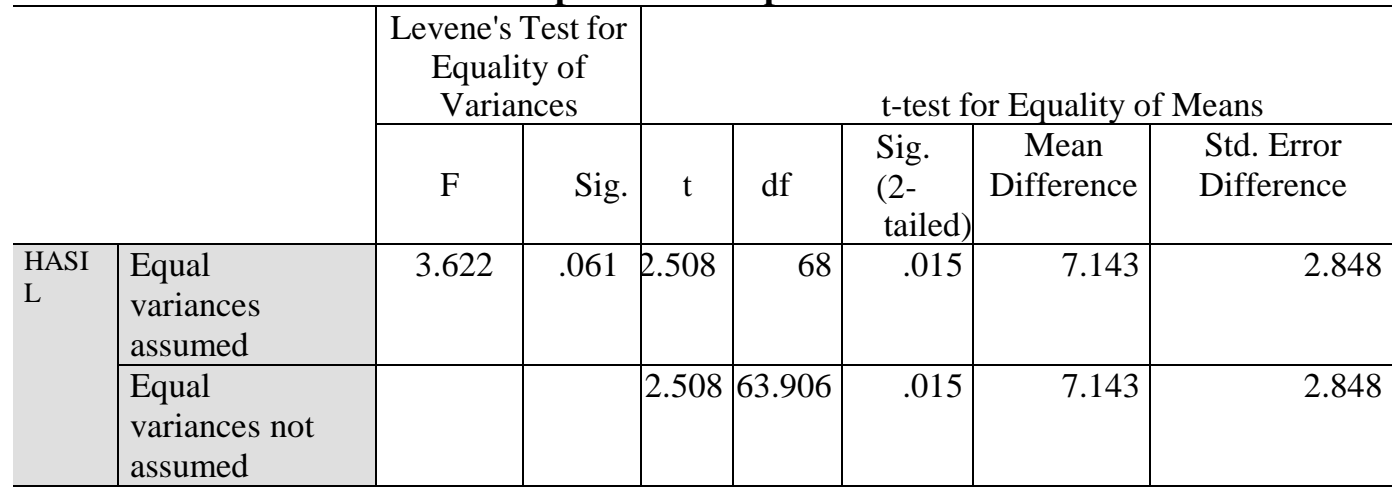

Berdasarkan tabel hasil perhitungan SPSS di atas diperoleh nilai probabilitas (Asymp.Sig(2-tailed) adalah 0,015 < 0,05, sehingga H0 diterima yang artinya ada perbedaan kemampuan penalaran matematis siswa antara kelas X IPA 1 (eksperimen) dan kelas X IPA 4 (kontrol).

Tabel 9. Pretes Pemecahan Masalah

\begin{tabular}{|c|c|c|c|c|c|}
\hline \multicolumn{6}{|c|}{ Group Statistics } \\
\hline & kelompok & $\mathrm{N}$ & Mean & Std. Deviation & Std. Error Mean \\
\hline \multirow[t]{2}{*}{ hasil } & IPA 1 & 35 & 66.57 & 14.490 & 2.449 \\
\hline & IPA 4 & 35 & 66.86 & 17.196 & 2.907 \\
\hline
\end{tabular}

Berdasarkan hasil perhitungan SPSS di atas dapat diketahui bahwa jumlah siswa kelas X IPA-1 (eksperimen) adalah 35 orang dengan nilai rata-rata 66.57. Sedangkan jumlah siswa kelas X IPA-4 (kontrol) adalah 35 orang dengan nilai rata- rata 66.86.

Tabel 10. Uji T Pretes Pemecahan Masalah

\begin{tabular}{|c|c|c|c|c|c|c|c|c|}
\hline \multicolumn{9}{|c|}{ Independent Samples Test } \\
\hline & & \multicolumn{2}{|c|}{$\begin{array}{c}\text { Levene's Test } \\
\text { forEquality of } \\
\text { Variances }\end{array}$} & \multicolumn{5}{|c|}{ t-test for Equality of Means } \\
\hline & & $\mathrm{F}$ & Sig. & $\mathrm{t}$ & df & $\begin{array}{l}\text { Sig. (2- } \\
\text { tailed) }\end{array}$ & $\begin{array}{c}\text { Mean } \\
\text { Difference }\end{array}$ & $\begin{array}{c}\text { Std. } \\
\text { Error } \\
\text { Differenc } \\
\text { e }\end{array}$ \\
\hline \multirow[t]{2}{*}{ hasil } & $\begin{array}{l}\text { Equal } \\
\text { variances } \\
\text { assumed } \\
\end{array}$ & 1.654 & .203 & -.075 & 68 & .940 & -.286 & 3.801 \\
\hline & $\begin{array}{l}\text { Equal } \\
\text { variances not } \\
\text { assumed }\end{array}$ & & & -.075 & 66.099 & .940 & -.286 & 3.801 \\
\hline
\end{tabular}

Berdasarkan tabel hasil perhitungan SPSS di atas diperoleh nilai probabilitas (Asymp.Sig(2- tailed) adalah 0,940>0,05, sehingga H0 diterima yang artinya tidak ada perbedaan kemampuan pemecahan masalah siswa antara kelas X IPA 1 (eksperimen) dan kelas X IPA 4 (kontrol). 
Tabel 11. Postes Pemecahan masalah

\begin{tabular}{|c|c|c|c|c|c|}
\hline \multicolumn{6}{|c|}{ Group Statistics } \\
\hline & KELOMPOK & $\mathrm{N}$ & $\begin{array}{c}\text { Mea } \\
\text { n }\end{array}$ & $\begin{array}{l}\text { Std. } \\
\text { Deviation }\end{array}$ & Std. Error Mean \\
\hline HASIL & IPA 1 & 35 & 82.57 & 10.872 & 1.838 \\
\hline & IPA 4 & 35 & 74.43 & 12.821 & 2.167 \\
\hline
\end{tabular}

Berdasarkan hasil perhitungan SPSS di atas dapat diketahui bahwa jumlah siswa kelas X IPA-1 (eksperimen) adalah 35 orang dengan nilai rata-rata 82.57. Sedangkan jumlah siswa kelas X IPA-4 (kontrol) adalah 35 orang dengan nilai rata-rata 74.43 .

Tabel 12. Uji t Postes Pemecahan masalah

\begin{tabular}{|c|c|c|c|c|c|c|c|c|}
\hline \multicolumn{9}{|c|}{ Independent Samples Test } \\
\hline & & \multicolumn{2}{|c|}{$\begin{array}{l}\text { Levene's Test } \\
\text { forEquality of } \\
\text { Variances }\end{array}$} & \multicolumn{5}{|c|}{ t-test for Equality of Means } \\
\hline & & $\mathrm{F}$ & Sig. & $\mathrm{t}$ & $\begin{array}{l}\mathrm{d} \\
\mathrm{f}\end{array}$ & \begin{tabular}{l|} 
Sig. \\
$(2-$ \\
tailed \\
) \\
\end{tabular} & \begin{tabular}{l}
\multicolumn{1}{c}{ Mean } \\
Differen \\
ce
\end{tabular} & $\begin{array}{l}\text { Std. } \\
\text { Error } \\
\text { Differen } \\
\text { ce }\end{array}$ \\
\hline \multirow[t]{2}{*}{$\begin{array}{l}\text { HASI } \\
\text { L }\end{array}$} & \begin{tabular}{|l} 
Equal \\
varianc \\
es \\
assume \\
d
\end{tabular} & $\begin{array}{l}1.08 \\
3\end{array}$ & $\begin{array}{l}.30 \\
2\end{array}$ & $\begin{array}{l}2.86 \\
6\end{array}$ & 68 & .006 & 8.143 & 2.841 \\
\hline & $\begin{array}{l}\text { Equal } \\
\text { variances } \\
\text { notassumed }\end{array}$ & & & $\begin{array}{l}2.86 \\
6\end{array}$ & 66.231 & .006 & 8.143 & 2.841 \\
\hline
\end{tabular}

Berdasarkan tabel hasil perhitungan SPSS di atas diperoleh nilai probabilitas (Asymp.Sig(2-tailed) adalah 0,006 < 0,05, sehingga H0 diterima yang artinya ada perbedaan kemampuan pemecahan masalah siswa antara kelas X IPA 1 (eksperimen) dan kelas X IPA 4 (kontrol).

Dari penelitian yang telah dilaksanakan di SMA 22 Surabaya diperoleh 35 siswa yang mengikuti pembelajaran Problem Based Learning (kelas eksperimen) dan 35 siswa mengikuti pembelajaran konvensional (kelas kontrol). Setelah diperoleh data siswa yang akan dijadikan subjek penelitian, selanjutnya peneliti memberikan pretes materi SPLTV pada masing- masing kelas untuk mengetahui hasil kemampun awal penalaran matematis siswa dan pemecahan masalah siswa. Kemudian peneliti memberikan materi yang dapat digunakan dalam tiap kelas. Di kelas kontrol peneliti menggunakan pembelajaran yang telah diterapkan oleh guru yaitu hanya memberikan materi berupa PDF kepada siswa melalui via Whatsapp grup kemudian diberikan postest. Sedangkan pada kelas eksperimen peneliti memberikan materi secara online dengan pembelajaran Problem Based Learning kemudian diberikan postest untuk mengukur kemampuan penalaran matematis 
siswa dan kemampuan pemecahan masalah. 1. Pengaruh Problem Based Learning terhadap Kemampuan Penalaran
Matematis.

Dari hasil postest kemampuan penalaran matematis yang telah diberikan kepada siswa di kelas eksperimen dengan menerapkan pembelajaran Problem Based Learning diperoleh rata-rata kemampuan penalaran matematis siswa adalah sebesar 81,86, sedangkan di kelas kontrol menerapkan pembelajaran konvensional diperoleh rata-rata kemampuan penalaran siswa adalah sebesar 74,71. Hasil dari uji Independent sample t test yang telah dilaksanakan oleh peneliti diperolerh nilai probabilitas (Asymp. Sig (2-tailed) sebesar 0,015<0,05, sehingga H0 ditolak, yang artinya ada perbedaan kemampuan penalaran matematis siswa antara kelas $\mathrm{X}$ IPA-1 (eksperimen) yang menggunakan pembelajaran Problem Based Learning dan kelas X IPA-4 (kontrol) menggunakan pembelajaran konvensional. Model pembelajaran Problem Based Learning dapat membantu siswa agar memiliki keterampilan berpikir untuk menyelesaikan masalah serta meningkatkan ketarampilan intelektualnya terlebih lagi dalam pembelajaran matematika yang memerlukan keterampilan tersebut. Hal ini sejalan dengan penelitian yang dilaksanakan oleh Tina Sri Sumartini pada tahun 2015 bahwa siswa yang memiliki kemampuan penalaran matematis rendah lebih cocok diterapkan model pembelajaran Problem Based Learning agar terjadi peningkatan penalarannya. Setelah menerapkan pembelajaran Problem Based Learning diperoleh presentase kenaikan pada kelas eksperimen dilihat dari pretes ke postes sebesar 22,2\%, dibandingkan pada kelas kontrol dengan presentase kenaikan hanya mencapai $15,8 \%$ dari KKM. Di samping penggabungan aspek peningkatan penalaran matematis, model pembelajaran Problem Based Learning juga merupakan perpaduan berpikir kritis dan keterampilan memecahkan masalah. Dengan demikian terasa adanya kegiatan yang melatih kemampuan intelektualnya sehingga berpengaruh pada kegiatan penalaran.

2. Pengaruh Problem Based Learning terhadap Kemampuan Pemecahan Masalah Matematis.

Untuk melihat apakah terdapat perbedaan antara variabel bebas (X) dengan variabel terikat (Y2), dapat dilihat pada hasil postest kemampuan pemecahan masalah yang telah diberikan kepada siswa di kelas eksperimen dan kontrol. Diperoleh rata-rata kemampuan pemecahan masalahnya adalah sebesar 82,57, dan pada kelas kontrol rata-rata kemampuan pemecahan masalahnya adalah sebesar 74,43 . Proses perhitungan yang telah dilakukan oleh peneliti dengan uji perbedaan rata-rata diperoleh nilai probabilitas (Asymp. Sig (2-tailed) sebesar 0,006 < 0,05, sehingga $\mathrm{H} 0$ ditolak, yang artinya ada perbedaan kemampuan pemecahan masalah siswa antara kelas X IPA-1 (eksperimen) yang menggunakan pembelajaran Problem Based Learning dan kelas X IPA-4 (kontrol) yang menggunakan pembelajaran konvensional. Melalui pembelajaran berbasis masalah siswa dapat mengatasi kesulitan dalam memecahkan masalah. Hal ini dapat dipahami karena dalam pembelajaran problem based learning menggunakan masalah nyata yang biasa ditemui oleh siswa dalam kehidupan sehari-hari. Pembelajaran ini biasanya dilakukan dalam kelompok kecil sehingga dapat mengatasi kesulitan belajar siswa dengan saling berinteraksi yang dapat membantu proses pemecahan masalah 
dengan saling membantu antar anggota kelompok. Selain itu, dalam kerjasama kelompok dapat megurangi ketergantungan siswa terhadap guru, menurunkan perilaku yang menggangu proses pembelajaran, dan meningkatkan kemampuan memecahkan masalah. Hal ini sesuai dengan penelitian yang dilakukan oleh Ana Setiani pada tahun 2016 yang menyatakan bahwa : "Diperoleh nilai sig (2tailed)nya $0,000<0,05$. Artinya rerata postest kemampuan pemecahan masalah matematis kelas eksperimen dan kelas kontrol berbeda. Dari hasil analisis dapat disimpulkan bahwa pada $\alpha=0,05$, terdapat perbedaan kemampuan awal pemecahan masalah matematis antara siswa kelas eksperimen dan kelas kontrol."

Dengan demikian pembelajaran Problem Based Learning memberikan pengaruh pada proses pemecahan masalah siswa. Di samping itu Problem Based Learning juga memiliki keterkaitan dengan kemampuan pemecahan masalah siswa. Menurut penelitian yang dilakukan oleh Frisca Wulandari pada tahun 2016 menyatakan bahwa terdapat keterkaitan antara pembelajaran berbasis masalah dengan penalaran dan pemecahan masalah. Karena seseorang dengan daya nalar yang tinggi memiliki kemungkinan yang besar dalam memecahkan suatu masalah. Pembelajaran berbasis masalah menjadi hal yang utama untuk mempertinggi daya nalar dan pemecahan masalah.

Setelah diuji secara detail, jika dilihat dari rata-rata nilai siswa pada masing-masing kelas menunjukkan bahwa hasil yang didapatkan mencerminkan adanya pengaruh pembelajaran Problem Based Learning terhadap kemampuan penalaran dan pemecahan masalah pada kelas eksperimen. Dimana dalam proses pembelajaran tersebut dapat menciptakan suasana belajar yang lebih produktif dan tidak monoton. Melalui pembelajaran yang produktif siswa dapat menyerap materi yang dipelajari dengan baik sehingga siswa dapat menyelesaikan permasalahan yang diberikan. Dengan demikian, siswa akan melatih proses berpikirnya melalui kemampuan penalaran dan memecahkan masalah.

\section{KESIMPULAN}

Berdasarkan analisis data yang telah dilaksanakan oleh peneliti mengenai pengaruh pembelajaran Problem Based Learning terhadap kemampuan penalaran dan pemecahan masalah di SMAN 22 Surabaya, maka didapat beberapa kesimpulan sebagai berikut :

1. Ada pengaruh pembelajaran Problem Based Learning terhadap kemampuan penalaran matematis pada materi SPLTV yang diterapkan kepada siswa. Dapat dilihat dari perhitungan SPSS 25 yang diperoleh setelah menerapkan pembelajaran Problem Based Learning pada kelas eksperimen dan model pembelajaran konvensional pada kelas kontrol adalah menunjukkan nilai probabilitas (Asymp.Sig(2-tailed) sebesar 0,015 <0,05, sehingga H0 ditolak dan $\mathrm{H} 1$ diterima.

2. Ada pengaruh pembelajaran Problem Based Learning terhadap kemampuan pemecahan masalah pada materi SPLTV yang diterapkan kepada siswa. Dapat dilihat dari perhitungan SPSS 25 yang diperoleh setelah menerapkan pembelajaran Problem Based Learning pada kelas eksperimen dan model pembelajaran konvensional pada kelas kontrol adalah menunjukkan nilai probabilitas (Asymp.Sig(2-tailed) sebesar 0,006 <0,05, sehingga H0 ditolak dan $\mathrm{H} 1$ diterima. 


\section{DAFTAR PUSTAKA}

Kusumawardani, Dyah Retno, Wardono, and Kartono. 2018. "Pentingnya Penalaran Matematika Dalam Meningkatkan Kemampuan Literasi Matematika." Prisma 1(1): 588-95.

Liu, Min. 2005. Motivating Stundents Through Problem Based Learning. Texas: University of Texas.

Purnamasari, Pawestri Dian. 2015. "Analisis Kemampuan Pemecahan Masalah Matematika Siswa Kelas XI SMK Muhammadiyah I Patuk Pada Pokok Bahasan Peluang.” Universitas Negeri Yogyakarta.

Sariningsih, R., and R Purwasih. 2017. "Pembelajaran Problem Based Learning Untuk Meningkatkan Kemampuan Pemecahan Masalah Matematis Dan Self." Jurnal Nasional Pendidikan Matematika 1(1): 163.

Wulandari, Frisca. 2018. "Keterkaitan Kemampuan Penalaran Matematis Siswa Dengan Model Problem Based Learning (PBL)." In Seminar Pendidikan Matematika Ahmad Dahlan, Yogyakarta. 